\title{
MPG Gene
}

National Cancer Institute

\section{Source}

National Cancer Institute. MPG Gene. NCI Thesaurus. Code C94718.

This gene plays a role in DNA metabolism and repair. 